\title{
Valuing the Antigenicity of Sheep Milk Proteins after Fermentation at $40^{\circ} \mathrm{C}$
}

\author{
M. Missouri ${ }^{1, \text { * }, ~ A . ~ C h e k r o u n ~}{ }^{2}$, S. Belalia ${ }^{2}$, H. Mahdjoub Bessam ${ }^{1}$, O. Kheroua ${ }^{2}$ \\ ${ }^{1}$ Department of Biology, Faculty of Natural Sciences \& Life, Djillali Liabes University of Sidi Bel-Abbès, Sidi Bel-Abbès, Algeria \\ ${ }^{2}$ Laboratory of Physiology of Nutrition \& Food Security, Department of Biology, Faculty of Natural Sciences \& Life, University of Oran Es- \\ sénia, Oran, Algeria
}

Email address:

mmissouri22000@yahoo.fr (M. Missouri)

\section{To cite this article:}

M. Missouri, A. Chekroun, S. Belalia, H. Mahdjoub Bessam, O. Kheroua. Valuing the Antigenicity of Sheep Milk Proteins after Fermentation at $40^{\circ}$ C. Journal of Food and Nutrition Sciences. Vol. 3, No. 3, 2015, pp. 84-89. doi: 10.11648/j.jfns.20150303.11

\begin{abstract}
The main objective of this work is to show a fermentation influence by some associations of two lactic acid bacteria and three bifidobacteria on proteolysis and the antigenicity of sheep milk proteins. This latter freshly collected is skimmed, sterilized and inoculated by a mixed culture. The mixture is homogenized and incubated at $40^{\circ} \mathrm{C}$ until it is a curd. On these fermented milks previously lyophilized, were measured the rate of lactic acid product, bacterial counts, the rate of total protein, $\alpha-\mathrm{NH}_{2}$ functions and the antigenicity of three proteins ( $\beta$ - $\mathrm{Lg}, \alpha$-La and SA). The obtained averages are compared with the " $t$ " test of Student compared to sterile milk without ferment taken as control. The best proteolysis is achieved in the fermented milk by Streptococcus thermophilus (St) associated with Lactobacillus plantarum (Lp) with a high antigenic potential of $\beta$-Lg and the $\alpha$-La probably due to the detection of unmasked antigenic sites.
\end{abstract}

Keywords: Sheep Milk, Bacteria, Fermentation, Proteolysis, Antigenicity, Awareness, Female rabbits

\section{Introduction}

Milk proteins are the main compounds capable of specific reactions with the immune system. They, generally, have a strong antigenicity power and a wide variety of epitopes to the immune system [1,2]. Under certain conditions, an increase in intestinal permeability to these proteins could be associated in allergies development, intolerance, gastrointestinal inflammation and diarrhea related to the degree of digestion of these latters [3-6,1,7].

The degree of protein digestion, therefore, determines the phenomena of tolerance, sensitivity and allergy to food proteins $[8,4-7,1]$. To prevent these symptoms, a full eviction of all sources of dairy protein is required, but this approach can lead to stunted growth [9].

The use of alternative products such as fermented sheep milks and even of other mammals, is an interesting alternative concerning proteolysis and preventing of manifestations of allergy. No study shows the superiority of a hydrolyzate type over another. [10] Different types of technological treatments on these proteins gave only inconclusive results. The lactic fermentation is a biological means for changing the allergenic character of these proteins [9-11,3].
Bacterial proteolysis is a complex biochemical phenomenon involving many enzymes. The preparation of fermented milk by associating lactic acid bacteria and bifidobacteria plays a key role since it is a process that is performed in a controlled manner on proteins mainly resistant to digestion such as $\beta$-lactoglobulin and $\alpha$ lactalbumin ; these are known to be allergenic, that's why it is important to evaluate this proteolysis against the allergic risk $[10,3]$.

\section{Materials \& Methods}

\subsection{Preparation of Sheep Milk and Tested Bacterial Species}

Sheep milk, freshly collected, is previously skimmed at $4^{\circ} \mathrm{C}$ by centrifugation at $3000 \mathrm{rev} / \mathrm{min}$ and sterilized at $105^{\circ} \mathrm{C}$ during 10 minutes to destroy the enzymes and the naturally occurring bacteria. It is inoculated with a mixed culture from two pure cultures at a concentration of $5 \%$ each. The mixture is homogenized and incubated at $40^{\circ} \mathrm{C}$ until it is a curd. The used bacteria, have allowed us to prepare the following fermented milk: Streptococcus thermophilus + Bifidobacterium longum ( $\mathrm{St}+\mathrm{B}$ long), Streptococcus thermophilus + Bifidobacterium bifidum ( $\mathrm{St}+\mathrm{B}$ bif), Streptococcus thermophilus + Bifidobacterium infantis $(\mathrm{St}+$ 
B inf), Streptococcus thermophilus + Lactobacillus plantarum $(\mathrm{St}+\mathrm{Lp})$. On some of these fermented milks fermentation pattern and enumeration were measured. On the other previously lyophilized portion the levels of total protein, $\alpha-\mathrm{NH}_{2}$ functions released and the antigenicity of the main 3 proteins $(\alpha-\mathrm{La}, \beta-\mathrm{Lg}$ and SA) were measured, they are most implicated in the phenomena of allergy and their degradation products by ELISA.

\subsection{Enumeration of Bacteria}

Bacteria counting $(\mathrm{cfu} / \mathrm{ml})$ was performed on samples of fermented milk [12]. Streptococcus thermophilus, Lactobacillus plantarum species and bifidobacteria are counted respectively specific culture media: $\mathrm{M}_{17}$ [13], Man Regosa Scharpe (MRS) [14] and Trypticase-Phytone-Yeast (TPY) [15].

\subsection{Measurement of the Produced Acidity}

The amount of produced acid is expressed in degrees Dornic / liter of sheep's milk ( $\left.{ }^{\circ} \mathrm{D} / 1\right)$ [16].

\subsection{Measurement of the pH Change}

$\mathrm{pH}$, index of acidity developed in sheep milk during the fermentation, is measured as a function of time using a digital $\mathrm{pH}$ meter (inoLab).

\subsection{Proteolytic Activity of Bacteria}

\subsubsection{Total Protein}

The determination of the total protein content $(\mathrm{g} / \mathrm{mg}$ of lyophilisate) in the samples of fermented milk, is carried out by the technique of Lowry et al., [17].

\subsubsection{Determination of $\alpha-\mathrm{NH}_{2}$ Released Functions}

Bacterial proteolysis is assessed by measurement of $\alpha-\mathrm{NH}_{2}$ functions released $(\mu \mathrm{M} / \mathrm{mg}$ of lyophilized) in samples of fermented milk by the method of Doi et al., [18].

\subsection{Measuring the Antigenicity of Fermented Milk Proteins}

Measuring the antigenicity of proteins ( $\beta$-Lg, $\alpha$-La and SA) is performed by ELISA according Engvall \& Perlmann, [19]. It is expressed as $\mu \mathrm{g} / \mathrm{mg}$ of freeze-dried fermented sheep milk, with the corresponding serum antibodies produced by female rabbits of New Zealandwhich underwent parenterally a sensibilisation, followed by a collection of blood from the marginal ear vein.

Permission to use rabbits was obtained by the ethics committee of the Liabes Djillali University of Sidi Bel-Abbès. The general rules for health and use of laboratory animals recommended by the Council of the European Community [20] have been followed.

\subsection{Statistical Analysis}

For the statistical analysis, each operation has been repeated 5 times. Results are expressed as mean \pm standard error $(X \pm S E)$. The mean values were compared using the " $t "$ test of Student relative to that of the sterile sheep milk without ferment taken in the same experimental conditions (control). The difference between the two means has been usually considered significant when $\mathrm{p}<0.05$ and nonsignificant in the other cases.

\section{Results}

\subsection{Morphological Characterization of Ferments}

The realized tests showed that all the bacteria are Gram positive, non-motile, non spore and are negative catalase and oxidase. Their growth is favored in anaerobic.

\section{2. pH Variations Sheep Milk During Fermentation}

The fermentation of sheep milk at $40^{\circ} \mathrm{C}$ showed a progressive decrease in $\mathrm{pH}$ which explains a metabolic activity of the bacterial species taken in combination. Our results show that lower $\mathrm{pH}$ is obtained in fermented milk by the association of $(\mathrm{St}+\mathrm{Lp})(4,55 \pm 0,02)$; this $\mathrm{pH}$ is significantly lower than that of the sterile milk without ferment taken as a control $(6,68 \pm 0,01)(\mathrm{p}<0.001)$.

\subsection{Measurement of the Acidity Produced by the Bacteria Used in Combination}

Tested bacterial associations produce acid during the fermentation by degrading the sugars from sheep milk. Strongest acidification is obtained by the mixed culture ( $\mathrm{St}+$ Lp) $\left(71.00 \pm 0.71^{\circ} \mathrm{D}\right)$ compared to sterile milk without ferment taken as control $\left(22,80 \pm 0,58^{\circ} \mathrm{D}\right)(\mathrm{p}<0.001)$; it corresponds to a low $\mathrm{pH}(4,55 \pm 0,02)(\mathrm{p}<0.001)$, confirming the role of acidifying agent Streptococcus thermophilus.

\subsection{Enumeration (log cfu/ml), on Appropriate Culture Media, Bacteria Put Together}

Bacterial counting on appropriate selective media, shows that there is bacterial growth in all fermented milks and that all species have a symbiotic nature when they are put together.

The bacterial growth is of great variability and higher is $\mathrm{St}$ $\left(29,2.10^{7} \mathrm{cfu} / \mathrm{ml}\right)$ obtained with a parallel increase of Lp $\left(26,8 \cdot 10^{7} \mathrm{cfu} / \mathrm{ml}\right)$.

\subsection{Proteolytic Activity of the Bacteria During the Fermentation}

\subsubsection{Total Protein Content of Fermented Milk}

The results show that the tested bacterial associations differently degrade sheep milk protein and it is the combination of $(\mathrm{St}+\mathrm{Lp})$ that gives the lowest profile $(288,41$ $\pm 79,41 \mu \mathrm{g} / \mathrm{mg}$ of lyophilisate) compared to milk control $(498,16 \pm 2,88 \mu \mathrm{g} / \mathrm{mg}$ of lyophilisate) a decrease of $42 \%$ $(\mathrm{p}<0.05)$ (Figure 1).

\subsection{2. $\alpha-\mathrm{NH}_{2}$ Functions Liberated in Fermented Milks}

The best proteolysis of sheep milk protein is obtained by (St + B long) with a functions value of $\alpha-\mathrm{NH}_{2}$ free of $(84,28$ 
$\pm 8,60 \mu \mathrm{M} / \mathrm{mg}$ of lyophilisate) against $(16,62 \pm 0,71 \mu \mathrm{M} / \mathrm{mg}$ of lyophilisate) to the sterile milk (control) $(\mathrm{p}<0.001)$ (Figure 2).

\subsection{Measuring the Antigenicity of Proteins ( $\beta-L g, \alpha-L a, S A)$ of Fermented Milks}

The results (Figure 3) show that the $\beta$ - $\mathrm{Lg}$ is detected in all fermented milks but with a significantly higher rate by associating of (St + B long) $(2,61 \pm 0,15 \mu \mathrm{g} / \mathrm{mg}$ of lyophilisate) compared to the milk control $(0,43 \pm 0,08$ $\mu \mathrm{g} / \mathrm{mg}$ of lyophilisate) $(\mathrm{p}<0.001)$. The lowest rate for the antigenicity $\beta-\mathrm{Lg}$ is obtained by combining $(\mathrm{St}+\mathrm{Lp})(0,53 \pm$ $0,06 \mu \mathrm{g} / \mathrm{mg}$ of lyophilisate).

The results show that the $\alpha$-La is present in all fermented milks but with a significantly higher rate by associating ( $\mathrm{St}+$ B long) $(4,25 \pm 0,24 \mu \mathrm{g} / \mathrm{mg}$ of lyophilisate) compared to milk control $(2,48 \pm 0,25 \mu \mathrm{g} / \mathrm{mg}$ of lyophilisate $)(\mathrm{p}<0.001)$. A significantly decreased rate $(0,66 \pm 0,17 \mu \mathrm{g} / \mathrm{mg}$ of lyophilisate) is obtained by association ( $\mathrm{St}+\mathrm{Lp})$ compared to that of reference milk $(2,48 \pm 0,25 \mu \mathrm{g} / \mathrm{mg}$ of lyophilisate $)$ $(\mathrm{p}<0.02)$ (Figure 4).

The antigenic activity of SA is present in all fermented milks. The results (Figure 5) show that the antigenicity of the SA indicates that no significant difference was observed in the fermented milk by (St) associated with (Lp) and bifidobacteria. The highest antigenicity rate is obtained by combining ( $\mathrm{St}+\mathrm{B}$ bif) $(0,41 \pm 0,04 \mu \mathrm{g} / \mathrm{mg}$ of lyophilisate) compared to the milk control $(0,40 \pm 0,06 \mu \mathrm{g} / \mathrm{mg}$ of lyophilisate). The lowest rate is obtained by combining $(\mathrm{St}+$ B long) $(0,36 \pm 0,01 \mu \mathrm{g} / \mathrm{mg}$ of lyophilisate).

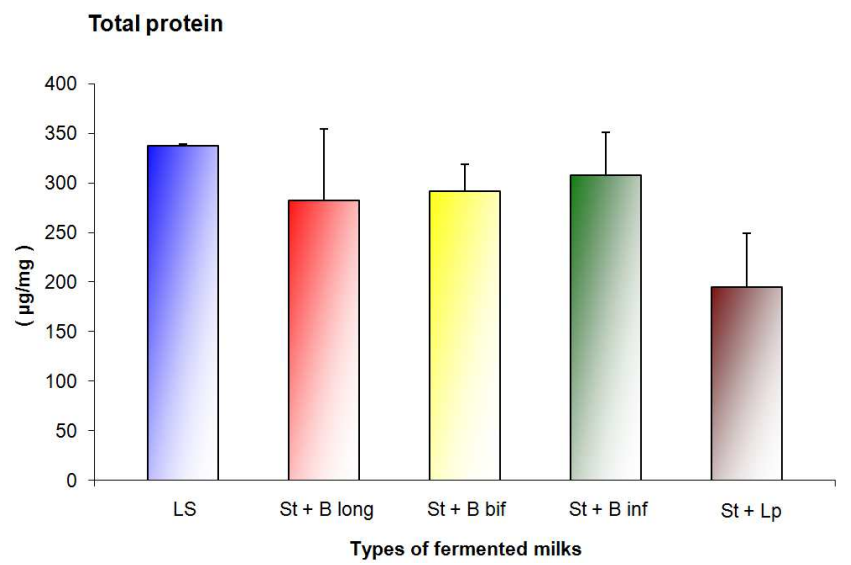

Figure 1. The amount of total protein ( $\mu \mathrm{g} / \mathrm{mg}$ of lyophilisate) fermented milks at $40^{\circ} \mathrm{C}$ by Streptococcus salivarius subsp. thermophilus (St) associated with Bifidobacterium longum (St $+B$ long) ; Bifidobacterium bifidum (St $+B$ bif) ; Bifidobacterium infantis (St $+B$ inf) ; Lactobacillus plantarum $(\mathrm{St}+\mathrm{Lp})$.

LS: sterile milk without ferment (control).

The values shown are mean \pm standard error $(X \pm S E)(n=5)$.

The averages were compared using the " $t$ " test of Student between :

The sterile milk (LS) and fermented milks (LF) ${ }^{*}$; Fermented Milks (LF) ${ }^{\bullet}$.

There is no significant difference between fermented milks and the witness.

${ }^{*} \mathrm{p}<0.05$ establishedonly difference $(\mathrm{St}+\mathrm{Lp})$ relative to the sterile milk without closing

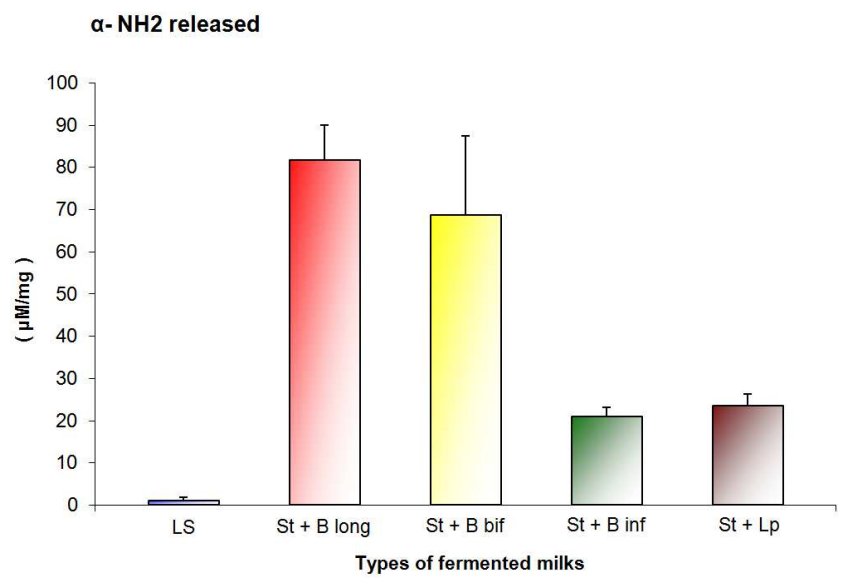

Figure 2. $\alpha-\mathrm{NH}_{2}$ functions released in micromoles/milligrams ( $\mu \mathrm{M} / \mathrm{mg}$ of lyophilisate) fermented sheep's milk at $40^{\circ} \mathrm{C}$ by Streptococcus salivarius subsp. thermophilus (St) associated with Bifidobacterium longum (St $+B$ long) ; Bifidobacterium bifidum (St $+B$ bif) ; Bifidobacterium infantis ( $S t$ $+B$ inf); Lactobacillus plantarum $(S t+L p)$.

LS: sterile milk without ferment (control).

The values shown are mean \pm standard error $(X \pm S E)(n=5)$.

The averages were compared using the " $\mathrm{t}$ " test of Student between :

The sterile milk (LS) and fermented milks (LF) ${ }^{*}$; Fermented Milks (LF) ${ }^{\bullet}$. ${ }^{* * *} \mathrm{p}<0.001^{* *} \mathrm{p}<0.01^{*} \mathrm{p}<0.05$ established differences respectively (St $+\mathrm{B}$ long $) ;(\mathrm{St}+\mathrm{B}$ bif $) ;(\mathrm{St}+\mathrm{B}$ inf $; \mathrm{St}+\mathrm{Lp})$ relative to the sterile milk without closing.

$$
\beta-\operatorname{Lg}
$$

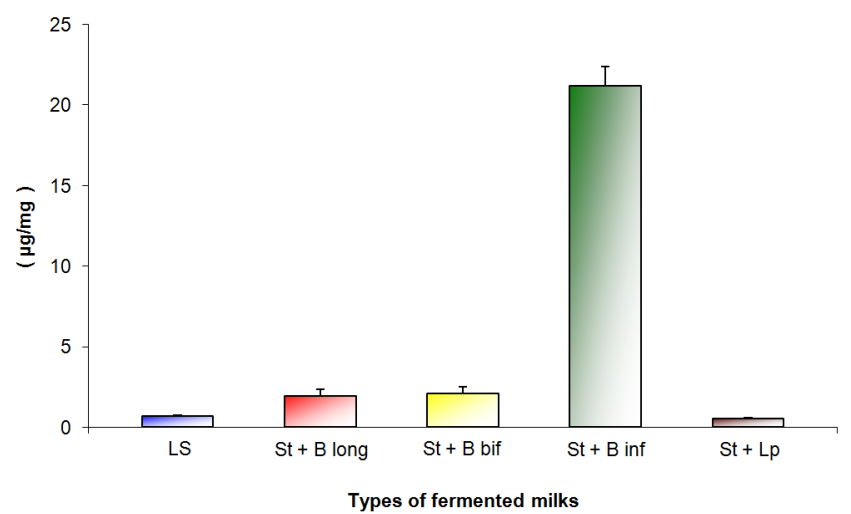

Figure 3. Measurement of residual antigenicity of $\beta$-lactoglobulin $(\beta$ - $L g$ ) ( $\mu \mathrm{g} / \mathrm{mg}$ of lyophilisate) in fermented milks at $40^{\circ} \mathrm{C}$ by Streptococcus salivarius subsp. thermophilus (St) associated with Bifidobacterium longum (St $+B$ long) ; Bifidobacterium bifidum (St $+B$ bif) ; Bifidobacterium infantis $(S t+B$ inf $)$; Lactobacillus plantarum $(S t+L p)$.

LS: sterile milk ferment without (control).

The values shown are mean \pm standard error $(X \pm S E)(n=5)$.

The averages were compared using the " $\mathrm{t}$ " test of Student between : The sterile milk (LS) and fermented milks (LF) ${ }^{*}$; Fermented Milks (LF) ${ }^{\bullet}$. ${ }^{* * *} \mathrm{p}<0.001$ only difference established ( $\mathrm{St}+\mathrm{B}$ long) compared to sterile milk without closing. ${ }^{\cdots \bullet} \mathrm{p}<0.001^{\bullet \bullet} \mathrm{p}<0.01$ respectivelydifferences established (St + B long ; St + B bif) ; (St + B bif ; St + B inf) compared to associations ( $\mathrm{St}$ $+\mathrm{Lp})$ and $\left(\mathrm{St}+\mathrm{B}\right.$ long) ${ }^{\bullet} \mathrm{p}<0.02$ difference established $(\mathrm{St}+\mathrm{B}$ inf) relative to the association ( $\mathrm{St}+\mathrm{B}$ bif). 


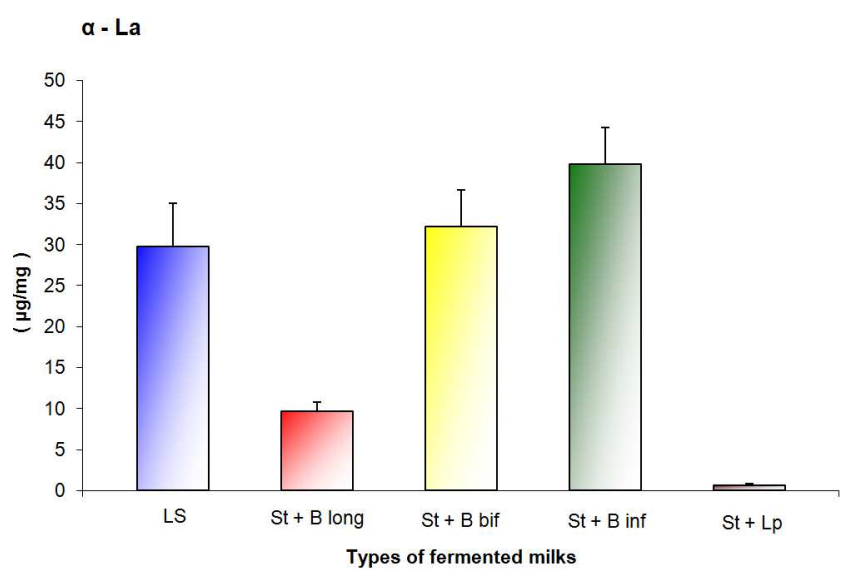

Figure 4. Measurement of residual antigenicity of $\alpha$-lactalbumin $(\alpha-L a)$ ( $\mu \mathrm{g} / \mathrm{mg}$ of lyophilisate) in fermented milks at $40^{\circ} \mathrm{C}$ by Streptococcus salivarius subsp. thermophilus (St) associated with Bifidobacterium longum (St $+B$ long) ; Bifidobacterium bifidum (St $+B$ bif) ; Bifidobacterium infantis (St $+B$ inf) ; Lactobacillus plantarum (St + Lp).

LS: sterile milk ferment without (control).

The values shown are mean \pm standard error $(X \pm S E)(n=5)$.

The averages were compared using the " $t$ " test of Student between : The sterile milk (LS) and fermented milks (LF) ${ }^{*}$; Fermented Milks (LF) ${ }^{\bullet}$.

$* * * \mathrm{p}<0.001 * * \mathrm{p}<0.02$ established differences respectively ( $\mathrm{St}+\mathrm{B}$ long) and $(\mathrm{St}+\mathrm{Lp})$ relative to the sterile milk without closing..

$\bullet \mathrm{p}<0.001{ }^{\bullet} \mathrm{p}<0.05$ established differences respectively (St $\left.+\mathrm{Lp}\right)$ and (St+ $\mathrm{B}$ inf) relative to the association $(\mathrm{St}+\mathrm{B}$ long).

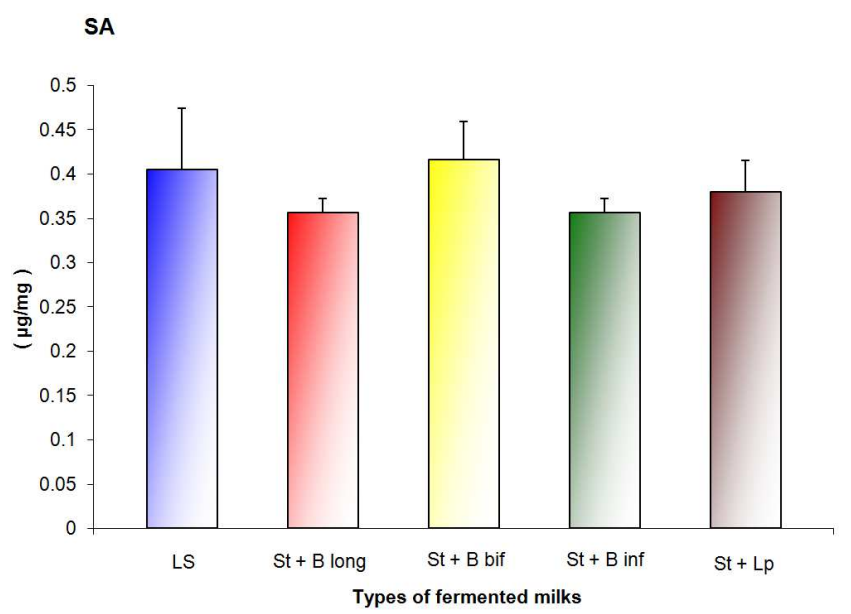

Figure 5. Measurement of residual antigenicity of serum albumin (SA) (ug/mg of lyophilisate) in fermented milks at $40^{\circ} \mathrm{C}$ by Streptococcus salivarius subsp. thermophilus (St) associated with Bifidobacterium longum (St + B long) ; Bifidobacterium bifidum (St + B bif) Bifidobacterium infantis $(S t+B$ inf $) ;$ Lactobacillus plantarum $(S t+L p)$.

LS: sterile milk ferment without (control).

The values shown are mean \pm standard error $(X \pm S E)(n=5)$.

The averages were compared using the " $\mathrm{t}$ " test of Student between :

The sterile milk (LS) and fermented milks (LF) ${ }^{*}$; Fermented Milks (LF) ${ }^{\bullet}$.

There is no significant difference between fermented milks and milk without closing the sterile and fermented milks them.

\section{Discussion}

This work's enterprise has been done in order to ferment sheep milk by various associations of Streptococcus thermophilus, Lactobacillus plantarum and bifidobacteria to alter the antigenicity of three major proteins from sheep milk $(\alpha-\mathrm{La} ; \beta-\mathrm{Lg}$ and SA) most implicated in allergy phenomena and their degradation products.

The bacteria used in this experiment are 5 ; they have been used in combination with a rate close to $5 \%$ for each of the tested bacteria [21]. This rate allows rapid sheep milk coagulation avoiding the proliferation of unwanted bacteria over long fermentation periods [14,22].

The results comparison concerning the production of acid shows that the bacterial associations have a greater acidifying power. Our results agree with those obtained by [22-23]. Our results also show that during the fermentation of the sheep milk at $40^{\circ} \mathrm{C}$, there is a significant decrease in the $\mathrm{pH}$ of the fermented milk compared to the milk control; this decrease in $\mathrm{pH}$ reflects the metabolic activity of the tested species. Our results agree with those obtained by [24].

The results of counting bacteria show that the slower growth of one or the other bacteria which constitute the association probably partially caused by products such as lactic acid and acetic acid which reduce the milk $\mathrm{pH}$ during fermentation [25-26].

The bacterial counts on appropriate specific areas, in prepared fermented milk, reveals that the used bacterial species are equipped with a proteolytic and acidifying activity [24,27]. The strongest and fastest bacterial growth in mixed culture is that of $(\mathrm{St})$ obtained with a parallel growth of (Lp). Our results agree with those obtained by [24], which explains the presence of a synergy between bacteria in mixed culture.

The mixture of bacterial species is clearly a more active example because each one benefits from the other making a symbiotic character. The results concerning the enumeration agree with those of [24,28-33] which have shown that certain bacterial strains stimulate growth of the other strains by producing nitrogen nutrients.

Sterilization at $105^{\circ} \mathrm{C}$ sheep's milk does not reduce the total protein rate. These results are in agreement with those of [34-36].

Concerning the bacterial proteolysis, our results showed that the tested mixed cultures degrade significantly the milk protein compared to the sterile sheep milk without leaven taken as control.

During the fermentation, the protein degradation by bacteria releases characteristic functions of proteolysis. The evaluation of these functions shows that all associations degrade significantly sheep milk proteins and the best proteolysis is obtained by the mixed culture : Streptococcus thermophilus and Lactobacillus plantarum. The protein hydrolysis by enzymes of bacteria can be explained by the existence of a protocooperation between the two germs on nitrogenous matter, so to boost their fermentation performance. Our results are in agreement with those of [14,25-26,37-38].

The results of determination of $\alpha-\mathrm{NH}_{2}$ functions released shows that mixed cultures have a variable proteolytic power depending on the type of the association and have an affinity to degrade a particular sheep's milk protein [23,25,38-39]. 
The age of the bacteria, the external $\mathrm{pH}$, incubation temperature and the pairing mode has an effect on the growth and proteolytic activity $[24,28,32,40]$.

The antigenicity of proteins in the samples of fermented sheep's milk ( $\beta$-Lg, $\alpha-\mathrm{La}$ and SA) and their degradation products, studied in vitro, by ELISA allowed us to quantify the reactivity with IgG specific anti- $\beta-\mathrm{Lg}$, anti- $\alpha-\mathrm{La}$ and antiSA [41].

Antigenic amounts of $\beta$-Lg, of $\alpha$-La and SA, detected in samples of fermented milks, increased during the lactic fermentation at $40^{\circ} \mathrm{C}$, and significantly for $\beta$-Lg and $\alpha$-La compared to those found in the sterile sheep milk without ferment taken as reference control. This is probably due to the fact that sheep's milk contains high levels of total protein and bacterial proteolysis has unmasked the hidden antigenic sites in the protein and degradation products. Thus, our results are also confirmed by the increase in $\alpha-\mathrm{NH}_{2}$ functions released by proteolysis and whose values depend on the type of association used, allowing thus make a selection of species for performing proteolytic activity.

The increase of the proteins antigenicity in the prepared fermented milk may be explained by the non-exposure of some epitopes on the action of certain enzymes on the one hand, or to the release of new antigens [34,42]. The values obtained have allowed us to better understand the true incidence of bacterial proteolysis. Knowledge of proteolytic enzymes of the latter, really active and their properties, can be of fundamental importance in the selection of starters $[26,30,43]$.

\section{Conclusion}

Following this study, the lactic acid fermentation is a process that revealed new antigenic sites in the degradation of sheep milk proteins by enzymes with an unmasking of antigenic epitopes initially hidden under the native form of the protein, but there are significant differences between the tested bacterial associations. Having said that our results will allow us to make the selection of the most efficient bacterial combination giving better proteolytic activity.

\section{References}

[1] D. De boissieu and C. Dupont, "Allergy to Extensively Hydrolysed Cow Milk Proteins in Infants," Archives de Pédiatrie Elsevier Masson Ed, Vol. 14, 2007, pp. 124-126.

[2] F. Rance and G. Dutau, "Actualités sur l'Exploration et la Prise en Charge de l'Allergie aux Protéines du Lait de Vache (APLV)," Revue Française d'Allergologie Elsevier Masson Ed, Vol. 49, 2009, pp. S28-S33.

[3] M. Heyman, "Food Antigens, Intestinal Barrier and Mucosal Immunity," Cahiers de Nutrition et Diététique, Vol. 45, 2010, pp. 65-71.

[4] J. P. Dessaint, "Tolérance ou Réactivité aux Allergènes," Revue Française d'Allergologie, Vol. 46, No. 3, 2006, pp. 125-27.
[5] S. Strobel and A.M.Mowat, "Oral Tolerance and Allergic Responses to Food Proteins," Current Opinion of Allergy and Clinical Immunology, Vol. 6, 2006, pp. 207-213.

[6] K. Adel-patient, S. Ah-leung, H. Bernard, D.A. Creminon and J.M. Wal, "Oral Sensitization to Peanut is Highly Enhanced by Application of Peanut Extracts to intact Skin, but is Prevented when CPG and Cholera Toxin are Added,'International Archives of Allergy and Immunology, Vol. 143, 2007, pp. 1020.

[7] A.C. Ouwehand,"Antiallergic Effects of Probiotics,"Journal of Nutrition, Vol. 137, No.Suppl 2, 2007, pp. S794-797.

[8] P. Chamberlin, "Immunogenicity of Therapeutic Proteins part J: Causes and Clinical Manifestations of Immunogenicity, the Regulatory,"Review, Vol. 5, 2002, pp. 4-9.

[9] G. Ernest, M.D. Seidman and M.D. Sanford Singer, "Therapeutic Modalities for Cow's Milk Allergy,"Annals of Allergy, Asthma \& Immunology, Vol. 90, 2003, pp. 104-11.

[10] J.P. Chouraqui, C. Dupont, A. Bocquet, H. Bresson, A. Briend, D. Darmaun and M.L. Frelut, "Feeding During the First Months of Life and Prevention of Allergy,"Archive de Pédiatrie, Vol. 15, No. 4, 2008, pp. 431-442.

[11] K. Adel-patient, H. Bernard and J.M. Wal, "Devenir des Allergènesdans le Tube Digestif, "Revue Française d'Allergologie \&d'Immunologie Clinique, Vol. 48, 2008, pp. 335-43.

[12] H.B. Ghoddusi and R.K. Robinson, "Enumeration of Starter Cultures in Fermented Milks, "Journal of Dairy Research,Vol. 63, 1996, pp. 151-158.

[13] B.E. Terzaghi and W.E. Sandine, "Improved Medium for Lactic Streptococci and their Bacteriophages, "Journal of Applied Microbiology, Vol. 29, 1975, pp. 807-813.

[14] J.C. De Man, M. Rogosa and M.E. Sharpe, "A Medium for Cultivation of Lactobacilli," Journal of Applied Bacteriology, Vol. 23, 1960, pp. 130-135.

[15] A.Y. Tamine, V.M.E. Marshall and R.K. Robinson,"Microbiological Aspects of Milks Fermented by Bifidobacteria,"Journal of Dairy Research, Vol. 62, 1995, pp. 151-187.

[16] J.P. Accolas, R. Bloquel and J. Regnier, "Propriétés Acidifiantes des Bactéries Lactiques Thermophiles en relation avec la Fabrication du Yaourt, " Revue Le Lait,Vol. 67, 1977, pp. 1-23.

[17] O.H. Lowry, N.H. Rosebrough, A.L. Fan and R.I. Randal, "Protein Measurement with Folin Phenol Reagent,"Journal of Biological Chemistry, Vol. 193, 1951, pp. 265-275.

[18] E. Doi, D. Shibata and T. Matoba,"Modified Colorimetric Ninhydrin Methods for Peptidase Assay, "Annals of Biochemistry, Vol. 118, 1981, pp. 173-184.

[19] E. Engvall and P. Perlmann, "Enzyme Linked Immunosorbent Assay (ELISA). Quantitative Assay of Globulin G," Journal of Immunochemistry, Vol. 8, 1971, pp. 871-874.

[20] Council of European Communities.Council Instructions about the Protection of Living Animals used in Scientific Investigations. Official Journal European Communities (JO 86/609/CEE); L 358: 1-28 (Corrigendum Official Journal L 117 of 05.05 .1987$) .1987$. 
[21] M.S. Garro, G.F. De Valdez and G.S. De Giori, “ Temperature Effect on the Biological Activity of Bifidobacterium longum CRL 849 and Lactobacillus fermentumCRL 251 in Pure and Mixed Cultures Grown in Soy Milk,"Journal ofFood Microbiology, Vol. 21,2004, pp. 511-18.

[22] C. Benjamas, S. Hiroshi and Suteaki S, “Enhanced Kefiran Production by Mixed Culture of Lactobacillus kefiranofaciens and Saccharomyces cerevisiae,"Journal of Biotechnology, Vol. 100, 2003, pp. 43-53.

[23] E.H.E Ayad, S. Nashat, N. El-sadek, H. Metwaly and M. Elsoda, "Selection of Wild Lactic Acid Bacteria Isolated from Traditional Egyptian Dairy Products According to Production and Technological Criteria,"Journal ofFood Microbiology, Vol. 21, 2004, pp. 715-25.

[24] A. Chekroun, A. Bensoltane, D. Saidi and O Kheroua, "Dietetic Valorisation of Cow's Milk Proteins Fermented at $45^{\circ} \mathrm{C}$ by Lactobacillus acidophilus Associated with Bifidobacteria," Journal of Agricultural Science and Technology, Vol. 5, No.3, Série 34, 2011, pp. 282-289.

[25] A.M. Gomes, F.X. Malcata and F.A. Klaver, "Growth Enhancement of Bifidobacteriumlactis Bo and Lactobacillus acidophilus Kid by Milk Hydrolysates, " Journal of Dairy Sciences, Vol. 81, 1998, pp. 281-285.

[26] J.F. Payne, A.E.J Morris and P. Beers, "Note: Evaluation of Selective Media for the Enumeration of Bifidobacterium sp. in Milk,” Journal of Applied Microbiology, Vol. 86, 1999, pp. 353-358.

[27] A. Shihata and N.P. Shah, " Proteolytic Profiles of Yogurt and Probiotic Bacteria,"International Dairy Journal, Vol. 10, 2000, pp. 401-408.

[28] M.A. Chopard, M. Schmitt, E. Perreard and J.F. Chamba, “Aspect Qualitatif de l'Activité Protéolytique des Lactobacilles Thermophiles utilisés en Fabrication de Fromages à Pâte Pressée Cuite, " Revue LeLait,Vol. 81, 2001, pp.183-94.

[29] T. Requena, J. Burton, T. Matsuki, K. Munro, M.A. Simon, R. Tanaka, K. Watanabe and G. Tannock, "Identification, Detection and Enumeration of Human Bifidobacterium Species by PCR Targeting the Transaldolase Gene,"Journal ofApplied and Environmental Microbiology, Vol. 68, No. 5, 2002, pp. 2420-2427.

[30] A. Bensoltane, A. Yagoubi, M. Mahi and A. Cheriguene, "Characterization of Lactic Acid Bacteria Isolated from Traditional Algerian Butter,"Egyptian Journal of Applied Sciences,Vol. 19, No. 11B, 2004, pp. 604-614.

[31] V. Hunsinger, "Maladies Inflammatoires du Réservoir Iléal réalisé après Anastomose Iléo Anale en cas de Rectocolite Hémorragique," " Le Rapport est disponible sur le Site de l'Agence de Sécurité Sanitaire des Aliments : www.afssa.fr " (C) Quotipharm (Tous droits réservés) 2005.

[32] A. Chekroun, A. Bensoltane, O. Kheroua, D. Saidi, "Biotechnological Characteristics of Fermented Milk by
Bacterial Association of the Strains Streptococcus, Lactobacillus and Bifidobacterium," Egyptian Journal of Applied Sciences,Vol. 21, No. 2b, 2006, pp. 583-598.

[33] A. Chekroun, A. Bensoltane, "Nutritional Characterization of Fermented Cow's Milk at $45{ }^{\circ} \mathrm{C}$ by Lactobacillusacidophilus Associated with Bifidobacteria,"Egyptian Journal of Applied Sciences, Vol. 22, No.12 A, 2007, pp. 188-202.

[34] D. Lorient, "Influence des Traitements Technologiques sur les Propriétés Nutritionnelles du Lait," Lait, Nutrition et SantéTechnique\& Documentation Ed Paris, 2001, pp. 193-207.

[35] S. Pougheon, "Le lait et ses Constituants : Caractéristiques Physico-Chimiques," Lait, Nutrition et Santé Technique\& Documentation Ed Paris, 2001, pp. 21-22.

[36] S.I. French, W.J. Harper, N.M. Kleinholz, R.B. Jones and K.B. Green-church, "Maillard Reaction Induced Lactose Attachment to Bovine $\beta$-Lactoglobulin: Electrospray Ionization and Matrix-Assisted Laser Desorption/Ionization Examination, "Journal of Agricultural and Food Chemistry, Vol. 50, 2002, pp. 820-823.

[37] T. Bintsis, A. Vafopoulou-mastrojiannaki, E. Litopouloutzanetaki and R.K. Robinson, "Protease, Peptidase and Esterase Activities by Lactobacilli and Yeast Isolates from Feta Cheese Brine,"Journal of Applied Microbiology, Vol. 95, 2003, pp. 68-77.

[38] I. Mierau, E.R. Kunji, G. Venema and J. Kok, "Casein and Peptide Degradation in Lactic Acid Bacteria,"Biotechnology Genetic Engineering Review, Vol. 14, 1997, pp. 279-301.

[39] P. Langella, S. Nouaille, J. Commissaire, A. Bolotine, A. Gruss and Le loir Y, "Expression Protéique (Protéone), Caractérisation des Facteurs d'Hôtes Affectant la Sécrétion de Protéines Hétérologues chez Lactococcus lactis," Revue LeLait,Vol. 81, 2001, pp. 19-28.

[40] B.Guessas and M. Kihal, "Characterisation of Lactic Acid Bacteria Isolated from Algerian Arid zone Raw Goats Milk,"African Journal of Biotechnology, Vol. 3, No. 6, 2004, pp. 339-342.

[41] D.A. Moneret-vautrin, R. Hatahet and G. Kanny, “ Hydrolysats de Protéines : Laits Hypoallergéniques et Formules Extensivement Hydrolysées. Bases Immunoallergologiques de leur Utilisation dans la Prévention et le Traitement de l'Allergie au Lait, "Archives de Pédiatrie Elsevier Ed,Vol. 8, 2001, pp. 1348-1357.

[42] F. Bonomi, A. Fiocchi, H. Frokiaer, A. Gaiaschi, S. Lametti, C Poiesi, P. Rasmussen, P. Restani and P. Rovere, "Reduction of Immunoreactivity of Bovine Bêta-lactoglobulin Upon Combined Physical and Proteolytic Treatment,"Journal of Dairy Research, Vol. 70, 2003, pp. 51-59.

[43] E.M. Guido, A. Warm, S. Arslanoglu and V. Mielo, "Management of Bovine Protein Allergy : New Perspectives and Nutritional Aspects,"Annals of Allergy, Asthma and Immunology, Vol. 86, No. 6 Suppl, 2002, pp. 1-93. 